\title{
Solid Waste Management Challenges and Its Impacts on People's Livelihood, Case of Kinyinya in Kigali City
}

\author{
Akimanizanye Victoire, Nsanzumukiza Vincent Martin*, Maniragaba Abias, \\ Uwayo Pacifique, Mucyo Jean Claude
}

Department of Environmental Information System, Faculty of Environment Studies, University of Lay Adventists of Kigali, Kigali, Rwanda

Email: ^nsanzumumartiv@gmail.com

How to cite this paper: Victoire, A., Martin, N. V., Abias, M., Pacifique, U., \& Claude, M. J. (2020). Solid Waste Management Challenges and Its Impacts on People's Livelihood, Case of Kinyinya in Kigali City. Journal of Geoscience and Environment Protection, 8, 82-96.

https://doi.org/10.4236/gep.2020.86007

Received: May 11, 2020

Accepted: June 27, 2020

Published: June 30, 2020

Copyright $\odot 2020$ by author(s) and Scientific Research Publishing Inc. This work is licensed under the Creative Commons Attribution International License (CC BY 4.0).

http://creativecommons.org/licenses/by/4.0/

(c) (i) Open Access

\begin{abstract}
The main intention of this study was to assess the solid waste management challenges and their impacts on people's livelihood. Specifically, the study evaluated the methods and techniques used for waste collection, transportation and deposit to the landfill by households, and companies in Kinyinya sector. A survey was conducted to collect data from household, waste collection company and field. Household waste collection, transportation and deposit illustrated different challenges which impede the sustainable treatment and disposal of waste. Findings pointed out poor deposit of wastes, failure to pay waste collection fees, poor assessment before selecting waste landfill and poor working condition of companies in charge of waste collection, transportation as the major challenges toward waste management in Kinyinya. The findings illustrated that only $33.25 \%$ of households separated decay from undecayed waste and $66.75 \%$ couldn't perform such activities. The findings indicated that members of some households suffered waste borne diseases from poor waste management. The linear correlation coefficient has shown $84.5 \%$ of correlation level between waste management challenges and people's livelihood $(r=0.845)$ and this correlation is statistically significant. Thus, poor waste management is one among factors of poor people's livelihood. The adaptation of segregation of waste at the household, strengthening company capacity and training workers at the landfill would save life and reduce exposure of both household and landfill workers.
\end{abstract}

\section{Keywords}

Solid Waste, Management Challenges, Waste Borne Disease, People's Livelihood 


\section{Introduction}

Solid waste management is a universal issue that matters to every single person in the world and with over $90 \%$ of waste openly dumped or burned in low-income countries, the poor people are most vulnerable and are disproportionately affected (Rodic et al., 2010). Around the world, waste generation rates are increasing; in 2016, the worlds' cities generated 2.01 billion tons of solid waste, amounting to a footprint of 0.74 kilograms per person per day (Ferronato \& Torretta, 2019). With rapid population growth and urbanization, annual waste generation is expected to increase by $70 \%$ from 2016 levels to 3.40 billion tones in 2050 (Wilson \& Webster, 2018). Compared to those in developed nations, residents in developing countries, especially the poor living in urban, are more severely impacted by unsustainably managed waste (Kaza et al., 2018). In low-income countries, over $90 \%$ of waste is often disposed in unregulated dumps or openly burned (Oyedele, 2016). The poor waste practices create serious health, safety, and environmental consequences. Poorly managed waste serves as a breeding ground for disease vectors, which contributes to global climate change through methane, carbon dioxide generation, and can even promote urban violence (Wilson \& Webster, 2018). Managing waste properly is essential for building sustainable and livable cities, but it remains a challenge for many developing countries and cities (Chandak, 2010). Effective waste management is expensive, often comprising $20 \%$ to $50 \%$ of municipal budgets (Wilson \& Velis, 2015). Operating this essential municipal service requires integrated systems that are efficient, sustainable, and socially supported (Wilson \& Webster, 2018).

In many African cities, the amount of solid waste is increasing rapidly due to population expansion and urbanization (Bello et al., 2016). Africa is characterized by the fastest-growing population, where a huge expansion can be observed in many cities in Africa, south of sub-Sahara, where the urbanization rate exceeds 5\% (Song \& Li, 2014), similarly to countries in East Asia, South Asia, and the Middle East (Godfrey et al., 2019).

Rwanda is facing significant challenges in relation to solid waste management; a sizeable portion of it is disposed on improper location and operated dumpsites, resulting in adverse impacts on environment and health (Kabera, 2020). The country has a backlog in waste legislation enforcement as well as in coordination and promotion of existing efforts to recycle and dispose waste properly. Solid waste management is becoming an important issue in Kigali City (Bazimenyera et al., 2012), with reference to the high population growth; previous research reported an increase of solid waste challenges in Kigali (Tsinda et al., 2013); collection of waste at the household and transportation were reported to be among serious challenges (Koushki et al., 2004; Das \& Bhattacharyya, 2015). Rwanda, being a densely populated country, is undergoing rapid urbanization and a huge number of people are leaving rural areas to Kigali City, this leads to an increasing of challenges associated with providing an effective basic infrastructure in- 
cluding solid waste management system. As cities grow, wastes generated increase in volume as well as in variety (Bazimenyera et al., 2012). A batch of wastes can be seen in various spaces such as roads, riversides and many other open spaces, and this constitutes a crucial problem to human beings in particular and environment in general, the accumulation of these wastes will attract rats, insects, flies and many other pathogens which in turn cause problems, such as water contamination, infectious diseases like diarrheal and so on (Karangwa, 2018). Reference to Kinyinya sector mission and its report (2019), the main issue facing companies collecting wastes in Kigali City, is linked to the households who failed to pay wastes fees on time and these who refused to pay the fees, which lead to illegally transportation of waste generated Some households are unable to separate solid wastes from other wastes such as decomposable and non-decomposable wastes (Sector, 2019). With reference to the issues of solid waste management in Kigali City, this paper intends to assess solid waste management challenges in $\mathrm{Ki}$ nyinya sector and its impact on people's livelihoods.

\section{Material and Methods}

\subsection{Study Areas Description}

The study area is located in Gasabo District, Kinyinya Sector (Figure 1). Gasabo district is one of four district of Kigali City and bordered by Kicukiro district (South), Nyarugenge (West), Rwamagana (East) and Rulindo and Gicumbi (North). The district's landscape or surface area is $430.30 \mathrm{~km}^{2}$ of which $90 \%$ represent rural areas (District, 2014) and urban areas (NISR, 2014). Kinyinya Sector is one of twelve sectors of Gasabo District, Nduba landfill is located in Nduba sector which in adjacent of Kinyinya sector. The target population for this study is households living in Kinyinya sector in cells bordering to Nduba landfill (for all Kigali City). Kinyinya sector was chosen purposively based on the location of the waste collection company, location of Nduba landfill and households living near landfill.

\subsection{Sampling Methodology and Data Collection}

Data used in this study were collected from various disseminated census, survey reports, field visit, observation and information provided with households living in Gasharu and Kagugu of Kinyinya sector. The purposive sampling was used to choose Kinyinya sector within Gasabo District. The cells were chosen purposively based on the location of the waste collection company and sub-branches of the company in Kinyinya cells. The household in each cell was selected randomly.

The total Households of 8928 distributed in 13 villages (Rwanda, 2012), were selected in Kagugu and Gasharu cells. To select the sample size among the population in Kagugu and Gasharu cell, the Equation (1) was used (Slovin, 1960). Equation (1) helps to ascertain the sample of a given population of the study.

$$
n=\frac{N}{1+N^{*}(e)^{2}}
$$




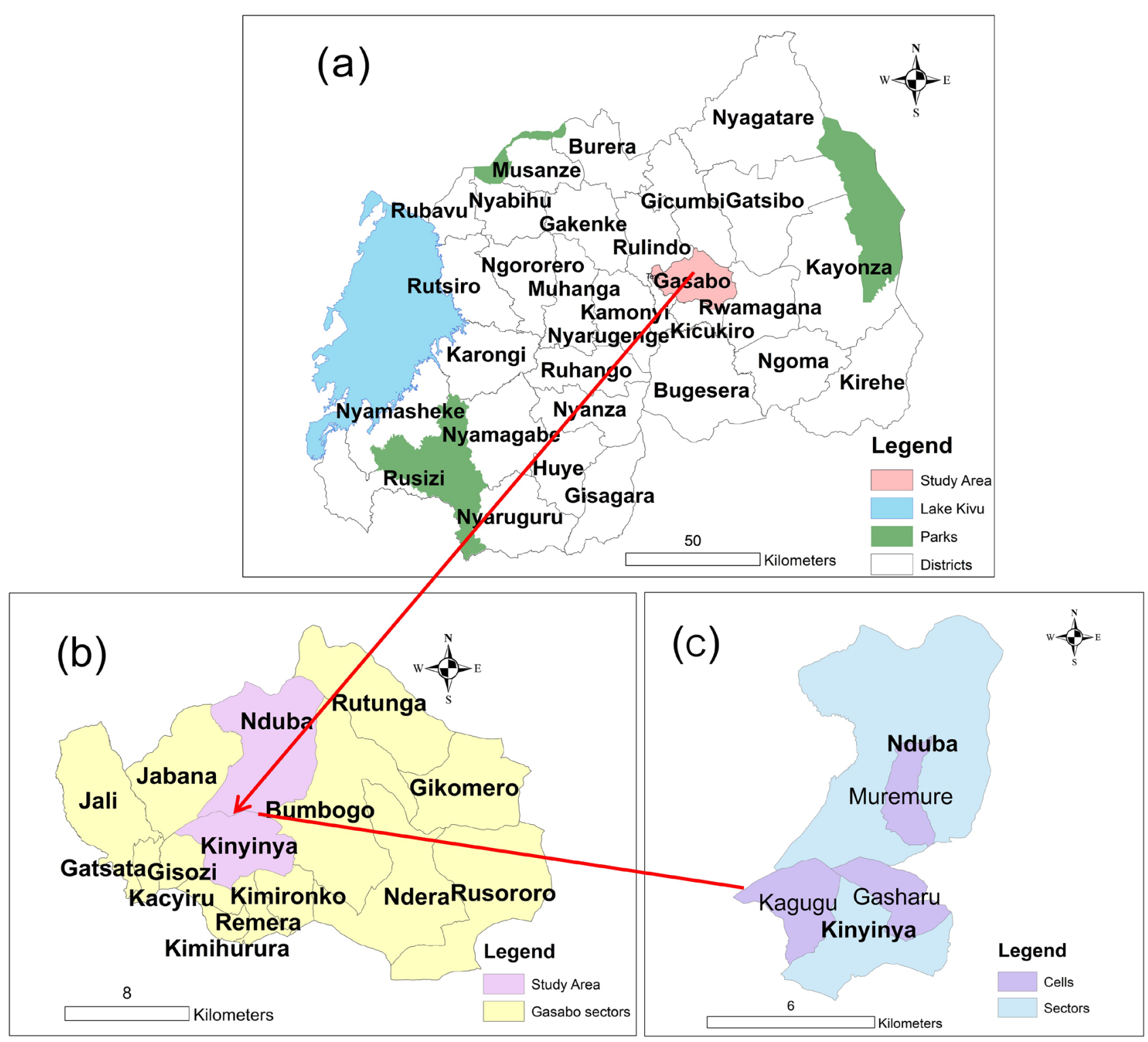

Figure 1. Map indicating the location of study areas (a) Map of Rwanda, (b) Kinyinya and Nduba sectors in Gasabo District map and (c) Kagugu and Gasharu Cells of Kinyinya sector and Nduba landfill in Muremure cell Nduba sector.

$N$ is the total population; $n$ is the sample size and $90 \%$ significance level or 0.1 . During the research, 99 households living in villages of Kagugu and Gasharu cells in Kinyinya Sector were contacted. In Kagugu and Gasharu, systematic sampling technique was applied for selecting households' interval in two respective cells. Household's interval is calculated in Equation (2):

$$
k^{\text {th }}=\frac{N}{n}
$$

where $k$ is the household interval, $N$ is total population and $\mathrm{n}$ is sample size. The sample size is presented in Table 1.

The household distribution and housing in Kinyinya sector were recorded in research reported by (Murangwa, 2018), Socio-Economic Survey (Habakubaho, 2020). 
Table 1. Population and sample distribution for the study.

\begin{tabular}{|c|c|c|c|c|}
\hline Cells & Villages & Total Households & Sample Size & Percentage \\
\hline \multirow[t]{5}{*}{ Gasharu } & Sub-Total & 2630 & 29 & 29.5 \\
\hline & Agatare & 700 & 8 & 7.8 \\
\hline & Gasharu & 786 & 9 & 8.8 \\
\hline & Kami & 489 & 5 & 5.5 \\
\hline & Rwankuba & 655 & 7 & 7.3 \\
\hline \multirow[t]{10}{*}{ Kagugu } & Sub-Total & 6298 & 70 & 70.5 \\
\hline & Dusenyi & 986 & 11 & 11 \\
\hline & Gicikiza & 685 & 8 & 7.7 \\
\hline & Giheka & 754 & 8 & 8.4 \\
\hline & Kabuhunde I & 658 & 7 & 7.4 \\
\hline & Kadobogo & 812 & 9 & 9.1 \\
\hline & Kagarama & 745 & 8 & 8.3 \\
\hline & Muhororo & 652 & 7 & 7.3 \\
\hline & Nyakabungo & 523 & 6 & 5.9 \\
\hline & Rukingu & 483 & 5 & 5.4 \\
\hline \multicolumn{2}{|c|}{ Grand-Total } & 8928 & 99 & 100 \\
\hline
\end{tabular}

\section{Results and Discussions}

Population growth, rapid urbanization, booming economy, and the increase in standards of living in a community have substantially enhanced the rate of municipal solid waste generation in developing countries (Minghua et al., 2009; Firdaus \& Ahmad, 2010; Marshall \& Farahbakhsh, 2013). Municipalities, generally responsible for management of waste in the cities, have the challenge to afford an efficient and effective system for the inhabitants. Nevertheless, there are problems beyond their abilities to cope with mostly because of the lack of financial resources, proper organization, complexity and system multi dimensionality (Rodic et al., 2010).

\subsection{Demographic Characteristics of Respondents}

Table 2 presents demographic characteristics of respondents of 99 households such as gender, marital status, educational level and years of living in Kinyinya Sector.

In other hands, waste handling is reported to be influenced with characteristics of respondents; it has been revealed that the key aspects of educating public improve knowledge on how to handle the waste (Martin et al., 2006). Through the education level, household were not characterized with the high profile of education where only $6 \%$ had attended college or university, $30.3 \%$ completed secondary education and high percentage of respondent have completed the 
Table 2. Background of respondents and sampled households.

\begin{tabular}{|c|c|c|}
\hline Background of Respondent & Frequency & Percentage \\
\hline \multicolumn{3}{|l|}{ Age (years) } \\
\hline Between 21 and 31 & 11 & $11.1 \%$ \\
\hline Between 31 and 50 & 83 & $83.6 \%$ \\
\hline 50 and above & 5 & $5.1 \%$ \\
\hline \multicolumn{3}{|l|}{ Sex of respondent } \\
\hline Male & 48 & $48.5 \%$ \\
\hline Female & 51 & $51.5 \%$ \\
\hline \multicolumn{3}{|l|}{ Marital status } \\
\hline Single & 7 & $7.1 \%$ \\
\hline Married & 77 & $77.8 \%$ \\
\hline Divorced/Separated & 6 & $6.1 \%$ \\
\hline Widow/Widower & 9 & $9.1 \%$ \\
\hline \multicolumn{3}{|l|}{ Educational Level } \\
\hline Primary & 63 & $63.6 \%$ \\
\hline Secondary & 30 & $30.3 \%$ \\
\hline Diploma & 3 & $3.0 \%$ \\
\hline First Degree & 3 & $3.0 \%$ \\
\hline
\end{tabular}

elementary school (63.6\%). The educated people are characterized with positive understanding on the effect of poor waste management on livelihood. With reference to gender, females' respondents were $51.5 \%$ and male respondent were $48.5 \%$. The $51 \%$ were male and $48 \%$ were female, and the average age of 39 years old.

\subsection{Waste Collection and Transportation}

Waste collection services are provided by private operators based on door-todoor collection; each household pay waste collection fees monthly. The company workers collect waste from each household to the company truck which transports the waste to Nduba landfill. Similar study has reported the same way of handling waste in Tanzania (Kassim \& Ali, 2006), but showed difference in structure. However, waste collection process is not done regularly which can result to human health and environment threat (Manga et al., 2011; Bleck \& Wettberg, 2012). The irregular service is mostly justified by limited capacities of collection companies and poor management system. The company in Kinyinya owns one or two collection trucks to provide services both to household and business entities. The business entities are considered the main customers of the service with higher priority.

In Table 3, it is shown that from 99 households assessed only $13.1 \%$ separate biodegradable and non-biodegradable solid waste and $86.9 \%$ of respondents 
Table 3. Households separating biodegradable and non-biodegradable.

\begin{tabular}{ccc}
\hline $\begin{array}{c}\text { Households separating biodegradable and } \\
\text { non-biodegradable solid waste }\end{array}$ & Frequency & Percent \\
\hline They separate biodegradable and non-biodegradable solid waste & 13 & 13.1 \\
They mix both biodegradable and non-biodegradable solid waste & 86 & 86.9 \\
Total & 99 & 100.0 \\
\hline
\end{tabular}

confirmed that they mix both biodegradable and non-biodegradable solid waste. The way people handled the waste presents a serious challenge to the local people in the vicinity. The way household store waste near the house hinders the performance of company workers to collect waste, such storage of cabbage include the mixing of biodegradable and non-biodegradable, sharp material (Bleck \& Wettberg, 2012). At the sector level, they have set the household waste payment system based on households' income production and VUP structure. The collection frequency for household and waste from business entities are somehow different and include as an additional parameter for business entities. In Kinyinya sector, generally households are charged with Frw 2000 (USD2.10) for low and middle-income households and Frw 5000 (USD5.25) for high income households. However, the business entities are charged based on the volume of waste daily produced.

\subsection{Lack of Sustainable Solid and Liquid Waste Management System}

Before the beginning of implementation of new Kigali City Master Plan in 2013, more than 300 tons of solid waste were collected every day and dumped into unsanitary landfill located in Nduba in Gasabo District (Isugi \& Niu, 2016). The method of waste disposal at Nduba landfill is still the same as the method used at Nyanza landfill (Kahigana, 2011), where wastes are deposited without separation and all landfills were created in short distance from households and hence causes the health risks. Disposal methods used at Nduba still expose citizens of City of Kigali to environmental and health hazards (REMA, 2018). Recycling is done at low level for plastic and glass bottles that are in large quantities at Nduba landfill to the extent that they have formed a heap. These bottles are mainly from breweries and companies that produce mineral water. The recycling is done at low pace for plastics by Ecoplastic Co while glass bottles are transported to Tanzania and Uganda where they are recycled (REMA, 2018). Previous research (Karangwa, 2018), reported that Solid waste management became an important issue in Kigali City. They reported that batch of wastes can be observed in different areas such as roads, riversides and many other in open spaces, and this constitutes a serious challenge to the Kigali City and pause a threat to human beings in particular and environment in general, the accumulation of such wastes attract rats, insects, flies and many other pathogens which in turn cause problems, such as water contamination, infectious diseases like diarrheal (Karangwa, 2018). Rwanda, 
being a densely populated country, is undergoing rapid urbanization and a high number of people are leaving rural areas to urban areas, this leads to an increasing of challenges associated with providing an effective basic infrastructure including solid waste management system (Karangwa, 2018).

\subsection{Solid Waste Management and Handling in Kinyinya}

In general, common storage facility is used for all kind of waste produced at household level (Suthar \& Singh, 2015), which results in the immediate mixing of biodegradable and non-biodegradable waste. Different equipment is used for storage of unseparated waste, which comprises mainly cartons, plastic buckets and sugar and rice bags. Kigali City's solid wastes are increasing in the quantity and quality as the number of population and economic activities are increasing (Isugi \& Niu, 2016), while the land for disposal is becoming scarce. Solid handling is serious challenges, some solid waste was packed from the household without separating biodegradable and non-biodegradable waste; this complicates the process at Nduba landfill. The consequence manifests in different forms such as spread of vermin and flies to the surrounding population which causes hygienic diseases, this was reported previously with different research (Minghua et al., 2009; REMA, 2018). As seen in Figure 2, some households or businesses (boutique and bars) drop wastes in non-proper area, if the wastes are not transported to landfill on time, the waste piled up in improper area are transported by water.

In Figure 2(a) illustrates places where people dump waste on road around the plots in Kinyinya, which is located on the map in Figure 3. Figure 2(b) shows the stock of waste deposited around the house, which present threats to health (Ko et al., 2020), Figure 2(c) showed a place where wastes were dumped in and
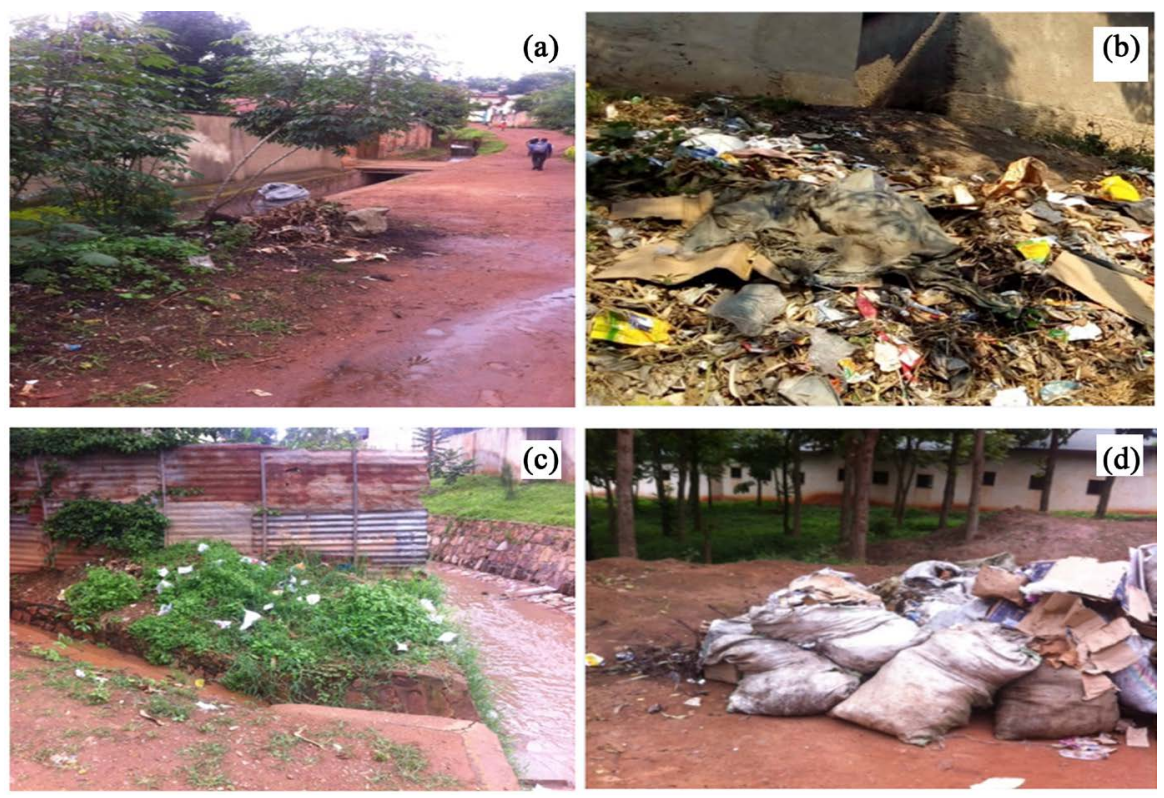

Figure 2. Cabbage distribution along different point in Kinyinya. 
around the water canal (Reza \& Yousuf, 2016), In addition to the poor waste management in different households, Figure 2(d) illustrates the way business entities put together the wastes while waiting for the truck which transport them to Nduba landfill but still wastes are not separated. The poor waste handling exposes people's lives and may cause livelihood problems to people in the area. Some people were reported to use the pit to handle the generated waste near their households, when the pits are located on the top of the hill or near the valley, if it rains heavily, they are likely to overflow and spread into the neighborhood and contaminate water and crops (Kim et al., 2015). This leads to spread of disease to the neighboring population (REMA, 2018). In other hand waste generated in rural area are treated through the composting process (Mihai, 2012; Mihai, 2015; Mihai \& Ingrao, 2018). In addition, there are 29 households on the gill in Rebero village, Gatunga Cell which are exposed to the health threats from Nduba landfill. Some households are located within 400 meters of the landfill and when it rains, solid waste slides towards their residences. Apart from the households, workers in Nduba landfill are highly exposed to serious health risks (REMA, 2018). It has indicated that low level of knowledge and poor waste management practices is the main reason of mishandling of the waste in the landfill and across the households (Pant, 2012). Lack of appropriate inspection exposes the landfill to harmful waste which is dangerous to the environment and health (REMA, 2018). Failure to monitor gases produced and emitted from the landfill lead to adverse impacts to the population in the vicinity of the landfill. The decomposition of the organic matter in anaerobic conditions generates methane gas which is a global warming gas and can cause combustion if not eliminated or reduced (REMA, 2018). Figure 3 illustrated the garbage collection point in Kinyinya sector and Figure 2 illustrated the view of management of the garbage in different collection sites.

The liquid waste (leachate) generates from the landfill is an environmental concern, contributes to bad smell, pollution of surface water, and nitrate contamination of groundwater. Ammonia emissions also contribute to the formation of fine particulates, which have a negative impact on animal and human health (REMA, 2018). Table 4 presents main mode of rubbish disposal (waste management) adopted by households in Rwanda. It illustrates the different strategy of handling the waste at household level including the Compost heaps on the household's own property and disposal in the household's fields in semi-urban and rural. The bushes dumping and Compost heap on own property are the main methods of rubbish disposal with $46.5 \%$ and $42.5 \%$ respectively. Very few households mainly dispose their rubbish in rivers, lakes or ditches, or burn it which represents a percentage of $0.2 \%$. The use of rubbish collection services in urban areas was reported to be $42.1 \%$. On the other hand, in the rural areas the percentages of households disposing their rubbish directly in bushes or fields were indicated to be $50 \%$. According to EICV5 ( $5^{\text {th }}$ Household living Condition Survey) results (Eurofound, 2012), Compost heaps on the household's own 


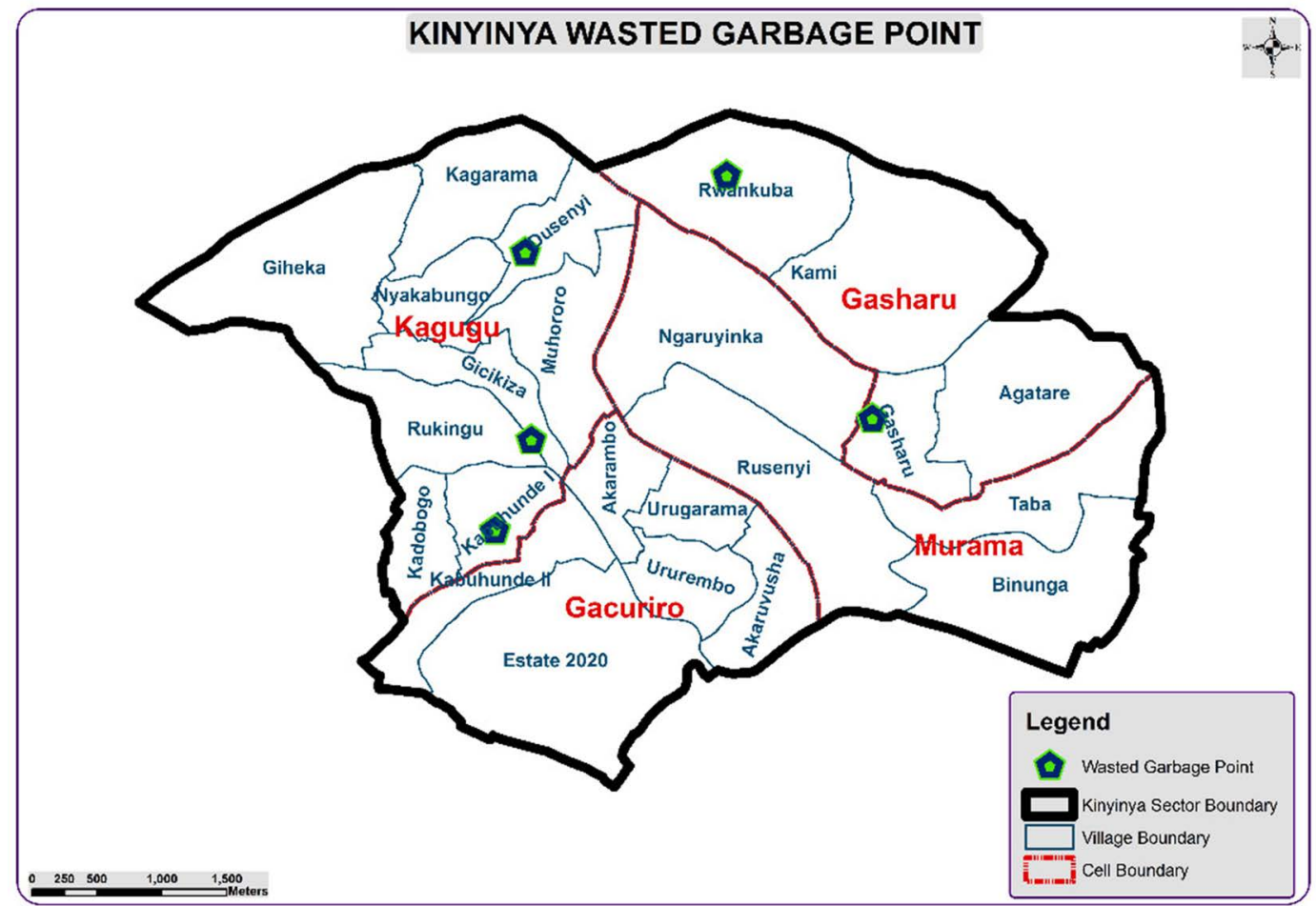

Figure 3. Mapping of waste cabbage point collection in Kinyinya Sector this map can be replaced by the following one which has high Resolution.

Table 4. Distribution (\%) of households by main mode of waste management, according to urban/rural, province and sex of head of household (EICV5).

\begin{tabular}{|c|c|c|c|c|c|c|c|c|c|}
\hline \multirow[b]{2}{*}{ EICV5 } & \multicolumn{7}{|c|}{ Main mode of rubbish disposal (waste management) } & \multirow[b]{2}{*}{ Total } & \multirow{2}{*}{$\begin{array}{c}\text { Total number } \\
\text { of households } \\
\text { (000 s) }\end{array}$} \\
\hline & $\begin{array}{l}\text { Publicly } \\
\text { managed } \\
\text { refuse area }\end{array}$ & $\begin{array}{l}\text { Rubbish } \\
\text { collection } \\
\text { service }\end{array}$ & $\begin{array}{l}\text { Thrown in } \\
\text { the HH's } \\
\text { fields/bushes }\end{array}$ & $\begin{array}{l}\text { Dumped in } \\
\text { river/lakes/ } \\
\text { ditches }\end{array}$ & Burnt & $\begin{array}{c}\text { Compost } \\
\text { heap on own } \\
\text { property }\end{array}$ & $\begin{array}{l}\text { Other ways } \\
\text { of rubbish } \\
\text { disposal used }\end{array}$ & & \\
\hline All Rwanda & 2.0 & 8.3 & 46.5 & 0.2 & 0.1 & 42.5 & 0.4 & 100 & 2708 \\
\hline \multicolumn{10}{|l|}{ Urban/rural } \\
\hline Urban & 4.2 & 42.1 & 30.8 & 0.4 & 0.3 & 21.5 & 0.7 & 100 & 524 \\
\hline Rural & 1.5 & 0.2 & 50.2 & 0.1 & 0.1 & 47.6 & 0.3 & 100 & 2184 \\
\hline \multicolumn{10}{|l|}{ Province } \\
\hline Kigali City & 2.6 & 48.9 & 33.5 & 0.7 & 0.3 & 13.6 & 0.3 & 100 & 410 \\
\hline Southern & 2.5 & 0.7 & 58.8 & 0.1 & 0.1 & 37.6 & 0.3 & 100 & 626 \\
\hline Western & 2.2 & 1.6 & 48.5 & 0.1 & 0.0 & 47.1 & 0.5 & 100 & 574 \\
\hline Northern & 1.6 & 1.1 & 50.5 & 0.0 & 0.0 & 46.2 & 0.5 & 100 & 422 \\
\hline Eastern & 1.3 & 1.0 & 38.7 & 0.1 & 0.1 & 58.5 & 0.2 & 100 & 677 \\
\hline \multicolumn{10}{|c|}{ Sex of head of household } \\
\hline Male & 2.1 & 8.7 & 44.6 & 0.2 & 0.1 & 44.0 & 0.3 & 100 & 2031 \\
\hline Female & 1.7 & 7.3 & 52.0 & 0.1 & 0.0 & 38.3 & 0.5 & 100 & 677 \\
\hline
\end{tabular}

Source: Murangwa, 2018. 
property and disposal in the household's fields and bushes are the main methods of rubbish disposal with $43 \%$ and $47 \%$ respectively (Murangwa, 2018). The use of rubbish collection services in urban areas between EICV4 (Perent-Thirion et al., 2007) and EICV5 (Eurofound, 2012), has increased from 36\% to $42 \%$. On the other hand, in the rural areas the percentage of households disposing their rubbish directly in bushes or fields has increased from $42 \%$ to $50 \%$ between EICV4 and EICV5. This change has been mostly pronounced in Eastern Province (Murangwa, 2018).

\subsection{Type of Solid Waste in Kinyinya}

Solid wastes composition in Kinyinya sector as shown in Figure 4 is mainly made by food residues up to $68 \%$, paper with $9 \%$, metal with $2 \%$ and textiles with $1 \%$. Previous research indicated that if organic waste is diverted for composting, it can be beneficial to agricultures (Nakasaki et al., 2005; Karnchanawong \& Suriyanon, 2011), as above $70 \%$ of the population engaged in the agriculture sector in Rwanda. The agricultural sector accounts for $33 \%$ of the national GDP (BNR, 2015).

In general, Rwanda's GDP has been growing at the rate of 7\% since 2014 (BNR, 2015). Currently, Kigali City has more than one million populations and the main landfill for waste is Nduba dumpsite. Nduba landfill was created in 2015 and is located in Muremure Cell, Nduba sector, Gasabo District and was designed to receive 450 tons of solid waste per day which includes between 300 to 350 tones centrally collected waste per day (Isugi \& Niu, 2016).

\subsection{Household Challenge Associated to Poor Solid Waste Management}

Table 5 indicates that from 99 households, only $41.4 \%$ household reported minor impact of waste to member of their families, however, 58.6\% of household reported that member of their families has contracted with waste borne disease. The finding illustrated that the skin infection was reported to be (19.2\%), tuberculosis

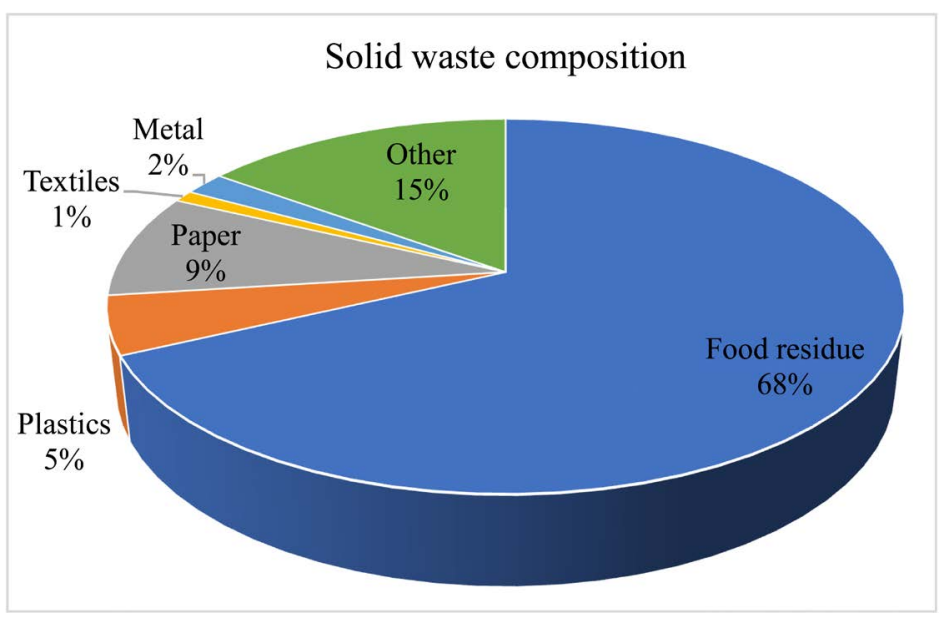

Figure 4. Solid waste composition. 
Table 5. Households with any member suffered any disease related to poor waste management must be placed in results discussion.

\begin{tabular}{ccc}
\hline Waste borne diseases & Frequency & Percent \\
\hline Tuberculosis & 9 & 9.1 \\
Diarrhea & 16 & 16.2 \\
RUTI/Respiratory Infections & 6 & 6.1 \\
Skin infection & 19 & 19.2 \\
Intestinal Parasites & 8 & 8.1 \\
Total (Household with any affected member) & 58 & 58.6 \\
Without any member affected & 41 & 41.4 \\
Total & 99 & 100 \\
\hline
\end{tabular}

(9.1\%), diarrhea (16.2\%), intestinal parasites (8.1\%) and RUTI/ Respiratory Infections (6.1\%). The effect of poor waste handling on public health was linked to throat infections, breathing (Kumar et al., 2017), dermatitis infections, skin irritation (Jerie, 2016) and respiratory disease (Ziraba et al., 2016). Waste borne diseases are likely to affect children and scavengers.

Table 5 indicates that deposit of solid waste near houses influence the children contamination which reflects in different kind of illness. The workers in the landfill are highly exposed to serious health risks (REMA, 2018). Bivariate analysis was performed for the households and their status for spearing decay waste from non-decay waste and their status for household member who suffered poor waste management diseases. The findings showed that Pearson correlation or $\mathrm{r}=$ 0.845 and $P<0.001$, which reveal positive and strong correlation between solid waste management and its impact on people's livelihood.

\section{Conclusion and Recommendation}

This study was conducted for assessing the solid waste management challenges and their impact on people's livelihood. Findings illustrated that poor deposit of wastes was due to low level of education and lack of skills and; some households failed to pay waste collection fees due to poverty or ignorance. The transportation and deposit to landfill are the major challenges toward waste management in Kinyina. The findings show that major solid wastes in Kinyinya sector are food residues (68\%), others occupy $15 \%$, metal (2\%), paper (9\%), plastics (5\%) and textiles (1\%). The results indicated that the poor handling of waste negatively affect people's livelihood through different illnesses; the finding illustrated that people in community are affected with waste borne diseases. The predominant methods for waste management were reported to be composting where wastes are dumped in field for further utilization. This report was mainly focused on Kinyinya sector adjacent to Nduba sector which accommodates Nduba landfill due to the limited time; however, further research is recommended to cover the whole districts of Kigali City to draw the general map of solid chal- 
lenge in Kigali and its impact on the people's livelihood.

\section{Conflicts of Interest}

The authors declare no conflicts of interest regarding the publication of this paper.

\section{References}

Bazimenyera, J. et al. (2012). Solid Waste Management in Kigali City, Rwanda. East African Journal of Science and Technology, 1, 46-58.

Bello, I. A. et al. (2016). Solid Waste Management in Africa: A Review. International Journal of Waste Resources, 6, 1-4. https://doi.org/10.4172/2252-5211.1000216

Bleck, D., \& Wettberg, W. (2012). Waste Collection in Developing Countries-Tackling Occupational Safety and Health Hazards at Their Source. Waste Management, 32, 2009-2017. https://doi.org/10.1016/j.wasman.2012.03.025

BNR (2015). National Account 2014: Gross Domestic Products and Compositions Kigali City. National Institute of Statistics of Rwanda (NISR).

Chandak, S. (2010). Trends in Solid Waste Management: Issues, Challenges and Opportunities. In International Consultative Meeting on Expanding Waste Management Services in Developing Countries.

Das, S., \& Bhattacharyya, B. K. (2015). Optimization of Municipal Solid Waste Collection and Transportation Routes. Waste Management, 43, 9-18. https://doi.org/10.1016/j.wasman.2015.06.033

District, G. (2014). Gasabo District Development Plan Report. Kigali, Gasabo District.

Eurofound (2012). Fifth European Working Conditions Survey.

Ferronato, N., \& Torretta, V. (2019). Waste Mismanagement in Developing Countries: A Review of Global Issues. International Journal of Environmental Research and Public Health, 16, 1060. https://doi.org/10.3390/ijerph16061060

Firdaus, G., \& Ahmad, A. (2010). Management of Urban Solid Waste Pollution in Developing Countries. International Journal of Environmental Research, 4, 795-806.

Godfrey, L. et al. (2019). Solid Waste Management in Africa: Governance Failure or Development Opportunity? In Regional Development in Africa. London: IntechOpen. https://doi.org/10.5772/intechopen.86974

Habakubaho (2020). Socio-Economic Survey for Kigali Water Supply Master Plan 2019-2050. Kigali: WASAC.

Isugi, J., \& Niu, D. (2016). Research on Landfill and Composting Guidelines in Kigali City, Rwanda Based on China's Experience. In Proceedings of the International Chemical, Biological and Environmental Engineering (pp. 24-25).

Jerie, S. (2016). Occupational Risks Associated with Solid Waste Management in the Informal Sector of Gweru, Zimbabwe. Journal of Environmental and Public Health, 2016, Article ID: 9024160. https://doi.org/10.1155/2016/9024160

Kabera, T. (2020). Solid Waste Management in Rwanda: Status and Challenges. In Sustainable Waste Management Challenges in Developing Countries (pp. 287-305). Hershey, PA: IGI Global. https://doi.org/10.4018/978-1-7998-0198-6.ch012

Kahigana, I. (2011). Selection and Implementation of an Optimal System to Handle Garbage in Kigali, Rwanda.

Karangwa (2018). Solid Waste Management in Kigali City. 
Karnchanawong, S., \& Suriyanon, N. (2011). Household Organic Waste Composting Using Bins with Different Types of Passive Aeration. Resources, Conservation and Recycling, 55, 548-553. https://doi.org/10.1016/j.resconrec.2011.01.006

Kassim, S. M., \& Ali, M. (2006). Solid Waste Collection by the Private Sector: Households' Perspective-Findings from a Study in Dar es Salaam City, Tanzania. Habitat International, 30, 769-780. https://doi.org/10.1016/j.habitatint.2005.09.003

Kaza, S. et al. (2018). What a Waste 2.0: A Global Snapshot of Solid Waste Management to 2050. Washington DC: The World Bank. https://doi.org/10.1596/978-1-4648-1329-0

Kim, K.-H. et al. (2015). A Review on the Human Health Impact of Airborne Particulate Matter. Environment International, 74, 136-143. https://doi.org/10.1016/j.envint.2014.10.005

Ko, S. et al. (2020). The Economic Value of Sustainable Recycling and Waste Management Policies: The Case of a Waste Management Crisis in South Korea. Waste Management, 104, 220-227. https://doi.org/10.1016/j.wasman.2020.01.020

Koushki, P. A. et al. (2004). Collection and Transportation Cost of Household Solid Waste in Kuwait. Waste Management, 24, 957-964. https://doi.org/10.1016/j.wasman.2004.03.013

Kumar, S. et al. (2017). Challenges and Opportunities Associated with Waste Management in India. Royal Society Open Science, 4, Article ID: 160764. https://doi.org/10.1098/rsos.160764

Manga, V. E. et al. (2011). Health Care Waste Management in Cameroon: A Case Study from the Southwestern Region. Resources, Conservation and Recycling, 57, 108-116. https://doi.org/10.1016/j.resconrec.2011.10.002

Marshall, R. E., \& Farahbakhsh, K. (2013). Systems Approaches to Integrated Solid Waste Management in Developing Countries. Waste Management, 33, 988-1003. https://doi.org/10.1016/j.wasman.2012.12.023

Martin, M. et al. (2006). Social, Cultural and Structural Influences on Household Waste Recycling: A Case Study. Resources, Conservation and Recycling, 48, 357-395. https://doi.org/10.1016/j.resconrec.2005.09.005

Mihai, F.-C., \& Ingrao, C. (2018). Assessment of Biowaste Losses through Unsound Waste Management Practices in Rural Areas and the Role of Home Composting. Journal of Cleaner Production, 172, 1631-1638. https://doi.org/10.1016/j.jclepro.2016.10.163

Mihai, F. (2012). Improper Household Waste Disposal in Rural Territory. Case Study: Neamt County. Bulletin UASVM Agriculture, 69, 15-20.

Mihai, F. (2015). Spatial Distribution of Rural Dumpsites Parameters in Romania. Bollettino Della Associazione Italiana Di Cartografia, 154, 90-98. https://doi.org/10.31235/osf.io/sg3j4

Minghua, Z. et al. (2009). Municipal Solid Waste Management in Pudong New Area, China. Waste Management, 29, 1227-1233. https://doi.org/10.1016/j.wasman.2008.07.016

Murangwa (2018). Households Living Condition Survey EICV5 (2016/17). Kigali: National Institute of Statistics of Rwanda (NISR).

Nakasaki, K. et al. (2005). Microbial Succession Associated with Organic Matter Decomposition during Thermophilic Composting of Organic Waste. Waste Management \& Research, 23, 48-56. https://doi.org/10.1177/0734242X05049771

NISR (2014). 4th General Population and Housing Census 2012. Kigali: National Institute of Statistics of Rwanda. 
Oyedele, O. (2016). Challenges of Urban Solid Waste Management in Developing Countries. Journal of Solid Waste Technology \& Management, 42.

Pant, D. (2012). Waste Management in Small Hospitals: Trouble for Environment. Environmental Monitoring and Assessment, 184, 4449-4453. https://doi.org/10.1007/s10661-011-2276-3

Perent-Thirion, A. et al. (2007). Fourth European Working Conditions Survey 2005. European Agency for Safety and Health at Work, Luxembourg, Office for Official Publications of the European Community.

REMA (2018). Environmental Management Strategies for National Strategy for Transformation (NST1). Kigali: MINECOFINE.

Reza, A., \& Yousuf, T. B. (2016). Impacts of Waste Dumping on Water Quality in the Buriganga River, Bangladesh and Possible Mitigation Measures. Journal of the Environment, 11, 35-40.

Rodic, L. et al. (2010). Comparing Solid Waste Management in the World's Cities. In ISWA World Congress.

Rwanda, N. I. (2012). Fourth Population and Housing Census.

Sector, K. (2019). Kinyinya Sector Report, Kinyinya Sector.

Slovin, E. (1960). Slovin's Formula for Sampling Technique.

Song, Q., \& Li, J. (2014). A Systematic Review of the Human Body Burden of e-Waste Exposure in China. Environment International, 68, 82-93. https://doi.org/10.1016/j.envint.2014.03.018

Suthar, S., \& Singh, P. (2015). Household Solid Waste Generation and Composition in Different Family Size and Socio-Economic Groups: A Case Study. Sustainable Cities and Society, 14, 56-63. https://doi.org/10.1016/j.scs.2014.07.004

Tsinda, A. et al. (2013). Challenges to Achieving Sustainable Sanitation in Informal Settlements of Kigali, Rwanda. International Journal of Environmental Research and Public Health, 10, 6939-6954. https://doi.org/10.3390/ijerph10126939

Wilson, D. C., \& Velis, C. A. (2015). Waste Management-Still a Global Challenge in the 21st Century: An Evidence-Based Call for Action. London: SAGE Publications. https://doi.org/10.1177/0734242X15616055

Wilson, D. C., \& Webster, M. (2018). Building Capacity for Community Waste Management in Low- and Middle-Income Countries. London: SAGE Publications.

Ziraba, A. K. et al. (2016). A Review and Framework for Understanding the Potential Impact of Poor Solid Waste Management on Health in Developing Countries. Archives of Public Health, 74, 55. https://doi.org/10.1186/s13690-016-0166-4 